\title{
Research on the Academic Senate System and Enlightenment of American Research Universities
}

\author{
Ruishu Wang ${ }^{1,2}$ and Wanbing $\mathrm{Shi}^{3{ }^{3 *}}$ \\ ${ }^{1}$ School of Humanities and Law, Northeastern University, Shenyang, Liaoning 110169, China \\ ${ }^{2}$ Foreign Studies College, Northeastern University, Shenyang, Liaoning 110819, China \\ ${ }^{3}$ Special Education Research Center, Nanjing Normal University of Special Education, Nanjing, Jiangsu 2100382, \\ China \\ *Corresponding author. Email: $1710011 @$ stu.neu.edu.cn
}

\begin{abstract}
This study aims to figure out the academic senate of American research universities by historical analysis method, documentary method and survey method. The academic senate in American universities has become an important part of the internal governance structure of American research universities. By studying the history and development, types, functions and responsibilities, operation model and characteristics of American research universities' academic senate, the results indicate that the academic senate is the representative organization for teachers to implement their academic power in American research.

Meanwhile, the academic senate is an institution that is separated from the administrative agency but cooperating with each other in American research universities. Third, the operation model of academic senate in American research universities is complete with reference value. By studying the academic senate system of American research university, it is of great importance to accelerate the development and construction of other modern universities' academic senate system.
\end{abstract}

Keywords: the academic senates, American research universities, characteristics, enlightenment

\section{INTRODUCTION}

In the second half of the 19th century, John Hopkins University officially established the first integrated university academic senate in the United States. Since then, the academic senate in American universities has developed gradually complete and become an important part of the internal governance structure of American research universities. It is an institution in which teachers participate in university governance set up by American research universities. Also, it is an institution for teachers to ensure their effective control over academic affairs and academic progress of the university. In American research universities, the academic senate, as a representative of academic authority, is composed of university professors or academic staff mainly composed of professors. It determines and manages the overall academic affairs of the university and has decision-making power over almost all academic affairs of the university. The academic senate of American research universities, as an organization for teachers to participate in the governance of university academic affairs, is well developed during these years. The successful experience of the academic senates of American research universities is of great significance for the development and construction of academic senates of other modern universities.
This paper studies the academic senate system of American research universities by using several different research methods and figures out its functions and responsibilities, characteristics and effective operating model. Then it analyzes the advanced experience of the academic senate system of American research universities to improve other universities' academic governance institutions which makes constructions to promoting the integral development of modern universities.

\section{HISTORY AND DEVELOPMENT OF THE ACADEMIC SENATES OF AMERICAN RESEARCH UNIVERSITIES}

\subsection{The Seed Period}

In 1650, when the dean of Harvard College formulated the school charter, he proposed to transform the board of trustees of Harvard College into a self-management institution including the dean, treasurer, and 5 teachers. However, this idea was not implemented because at that time, people believed that "outsiders" were more reasonable to run the school. Most of the members elected to the board of trustees were people "outside" school with business and public abilities, and professors gradually withdrew from decision-making organization. 


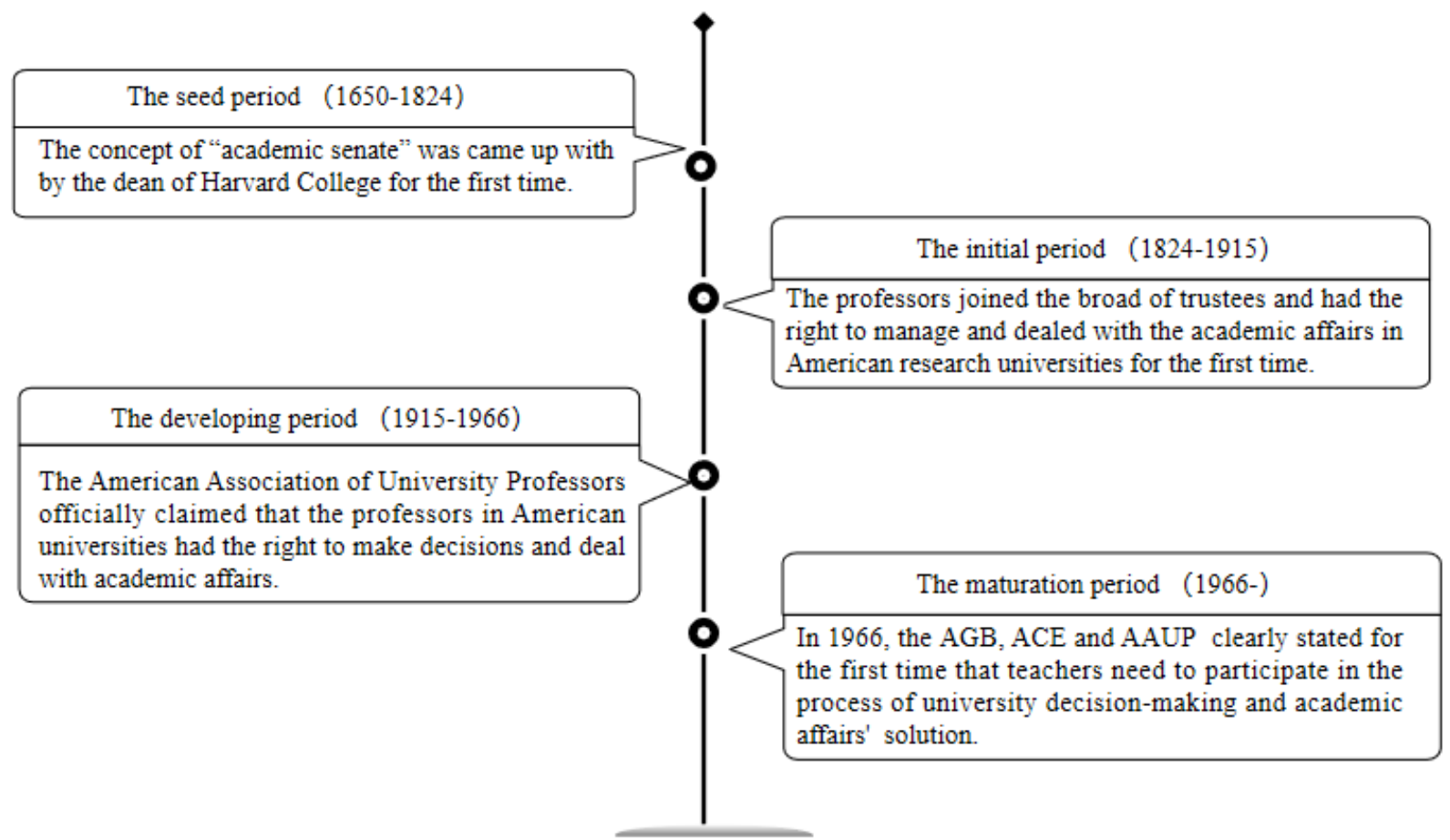

Figure 1. History and Development of Academic Senate of American Research Universities

\subsection{The Initial Period}

In 1824, nine professors of Harvard University jointly protested to the board of trustees that professors were excluded from decision-making organization. And the board of trustees held a meeting in 1825 and voted to decide that professors must be elected to decision-making organization. Then a professor joined the board of trustees as the representative of teachers to be responsible for students' examinations, dealing with the application of students, and some other affairs related to teaching. After that, professors devoted more to their work and play their roles better. Thus, the board of trustees of other universities gradually believed that the inclusion of professors in decision-making organizations could make school management developing better. They agreed that if there was no suggestion or agreement from the professor group, the major school academic policy should not be made. These institutions in which teachers participated in management had gradually improved. Teacher committees such as academic councils have been established at most universities and gradually gained the power to formulate university academic policies.

\subsection{The Developing Period}

The American Association of University Professors was established in 1915 which marked the beginning of a huge change in the status of teachers in American universities.
The statement of the Association of University Professors on the principles of academic freedom and the lifetime tenure of professors made to protect the academic freedom rights of teachers have gradually been recognized and accepted by many universities[1]. At that time, teachers from most American universities have established teacher organizations representing their interests and made them as representatives to participate in the decision-making of university academic affairs.

\subsection{The Maturation Period}

After the 20th century, the American university academic senate system has been further developed. Teachers in American universities consolidated their power in decision-making by establishing an academic senate or amending the academic senate's charter. And almost all universities have established academic senates. In 1966, the American Alliance of University Governance Boards, the American Council of Education, and the American Association of University Professors announced the "University Governance Declaration", which clearly stated for the first time that teachers need to participate in the process of university decision-making and academic affairs' solution. The name and functions of the organization of American university teachers to participate in university governance had been basically determined, and its system had been gradually improved. American university teachers gained the power to determine 
academic plans, curriculum settings, graduation standards, and the setting of university academic development goals. With the development of history, the strength of the academic senate of American universities has gradually strengthened. The status and role of American university academic senate in university academic management have also been continuously improved, and it has become the main force of university academic management[1].

\section{TYPES OF THE ACADEMIC SENATES OF AMERICAN RESEARCH UNIVERSITIES}

Based on the differences in governance structures and academic operation models, the types of research university academic senates in the United States are different. According to the function and role of academic senate in American research university governance, researchers divide American research universities' academic senates into the following categories: functional type, ceremonial type, influential type, and subverted type. The first one is the functional type. In this mode, the operation mode of the academic senate always safeguards the rights and interests of teachers. The tasks of the academic senate are implemented by the subordinate committees. The focus of the functional academic senate is on academic affairs such as teacher promotion, tenure professor appointment policy and academic standards. And it has little effect on non-academic standards affairs. This type of academic senate's power is very limited, and their main function is to protect the rights and status of teachers in universities. The second one is the ceremonial type. The academic senate of this model mainly deals with ritual affairs. The role of ceremonial academic senate is symbolic without real decision-making power over substantive affairs of the university. It has almost no impact on university governance which means that the ceremonial academic senate is only playing some potential functions. The third one is the influential type. Influential academic senates in American research universities handle academic affairs on behalf of teachers with legal powers. In American research universities with influential academic senates, the power of the university is mainly manipulated in the board of trustees and academic senates, which are in charge of administrative power and academic power. The academic senate has full power to formulate university academic policies. The principal is the main contact between the academic senate and the board of trustees, and mainly plays a role in balancing academic power and administrative power. The fourth one is the subverted type. The subverted academic senates generally have no practical effect and are always replaced by other forms of teacher participation. The power of this type of academic senate in American research universities is recommending degree candidates, etc. At the same time, the edit of related academic policies in American research universities must be approved by the academic senate. The last one is the conflict resolution function that mainly relatively weak, and teachers usually strive for the rights through collective bargaining. Meanwhile, other researchers have classified the types of American research universities with other principles. For example, Gan Yongtao believed that in the history of American higher education, the American research university academic senate system can be roughly divided into four types: European model type, conflict model type, functional model type, and influence model type[2]. Guo Weilu and Lin Chuili believed that according to the composition of the organization, the academic senate in American research universities can be divided into academic senates composed of all university teachers and academic senates composed of some teacher representatives[3]. Ge Xiyan believed that according to the division of power, the American research university academic senate is divided into a university-level academic senate and a college-level academic senate[4].

\section{FUNCTIONS AND RESPONSIBILITIES OF THE ACADEMIC SENATES OF AMERICAN RESEARCH UNIVERSITIES}

There are several functions of the academic senate in American research universities. The first one is the expressing interests' function. The academic senate is an organization that expresses teachers' needs. As an institution for teachers to participate in university governance. And it builds a relatively transparent and open dialogue platform for administrators and teachers. The second one is the advisor function. The academic senate of American research university mainly plays a consulting role in the governance of major academic affairs of universities such as providing consultation and advice for other related academic affairs in the university. The third one is the decision-making function. The main role of American research university's academic senate is to manage and make decisions for academic affairs of universities. The most important function of the academic senate is decision-making. The board of trustees delegates part of the decision-making power to the academic senate and the academic senate obtains the formal decisionmaking power. Based on legal authorization, the academic senate can perform its decision-making function. The fourth one is the legislative function that mainly refers to the statutory supervision responsibility of the teacher academic senate on the proposal, elaboration and amendment of academic policies. The academic senate is a normative organization for American research university teachers to implement governance power. It represents all teachers to implement legislative power on universities' academic affairs which includes teacher promotion, tenure policy, evaluation of teaching quality, admission requirements, course requirements, as well as refers to the teacher academic senate need to provide coordination strategies and methods for conflicts existing between teachers and managers and mediate the conflicts and contradictions between teachers and administrative 
officials. Because there is almost no clear boundary between many academic affairs and administrative affairs. As the representative governance organization of the teachers, the academic senate should be responsible for coordination and cooperation with administrative organization. It provides a platform for the teachers and the university administration to communicate and negotiate with each other.

The responsibilities of the American university academic senate mainly include that solving academic affairs, formulating academic policies, supervising academic activities, formulating academic policies and development plans, determining the assessment and employment of teachers and being responsible for the curriculum, teaching and academic exchange activities of students. It is also responsible for determining the admission standards and the standards for obtaining degrees, and managing the use of various teaching and research facilities in universities. The academic senate usually conducts collective deliberations and decision-making on important academic affairs through regular meetings and special meetings.

\section{THE RUNNING MODEL AND CHARACTERISTICS OF THE ACADEMIC SENATES OF AMERICAN RESEARCH UNIVERSITIES}

The academic senate of American research universities sets up subsidiary committees for dealing with universities' academic affairs by holding meetings. The members of the committee are formally appointed by the academic senate, but the committee members are actually selected by teachers. Before each meeting, the secretary of the academic senate must notify each member in a written notice. The agenda of the daily meeting is generally determined by the chairman of the academic senate. The meeting agenda and documents need to be distributed along with the meeting notice. For example, Stanford University's academic senate claims that the written notice of the meeting needs to be sent to members at least ten days before the actual meeting[5] and the University of Virginia academic senate requires that the notice of the meeting need to be sent by the secretary to all members of the academic senate at least one week before the meeting[6]. The meetings of academic senate of American research universities are generally held regularly. For example, MIT's academic senate holds a general meeting per week to confer academic affairs or policies[7]. Apart from the general meetings, some American research universities' academic senates generally hold special meetings which are generally proposed by the chairman of the academic senate, the executive committee of the academic senate or a certain number of members of the academic senate to discuss certain matters. For example, Boston University academic senate claims that as long as more than five percent of members apply for a special meeting to discuss academic affairs, then the meeting could be approved to be held[8]. And members need to discuss or vote on the academic affairs or policies issued by the university at the meeting.

There are three characteristics of the operating model of the American research university academic senate. The first one is that the academic power and administrative power are separated from each other. The board of trustees delegates the decision-making power of academic affairs to the academic senate, and the management of daily administrative affairs power to the principal and his administrative team. The academic senate represents and safeguards the interests and needs of academic staff and academic organizations and handles academic affairs with absolute decision-making power. The second one is that academic power and administrative power cooperate with each other. In the decision-making process of the academic senate of American research universities, academic power and administrative power are separated, but with cooperation. For example, principals and the vice principals of finance of universities will also participate in the academic senates. They need to communicate with teachers to understand their needs and thoughts. Meanwhile, when dealing with academic affairs, university education or research policies, the president must consult with the academic senate and solicits teachers' suggestions[9]. The last feature is that the decision-making process reflects the democratic power of teachers. The decision-making process of the American research university academic senate reflects the democratic and equal decision-making model of teachers. When voting for the decisions, all professors have the right to vote and the absolute right to make decisions for all academic affairs. Through this decision-making model, the American research university academic senate has become the support for representing and protecting the academic autonomy of university teachers, ensuring teachers' independent decision-making power on academic affairs.

\section{ENLIGHTENMENT AND CONCLUSION}

First of all, modern universities should clarify the status of the academic senate. In American research universities, the academic senate is an important institution composed of professors or academic staff of American research universities to propose and formulate university academic policies. It is an important feature of the management system of American research universities. The governance structure of American research universities not only maintains academic power, but also enables universities to operate efficiently. The academic senate is a vital management entity in the governance structure that is in charge of academic issues such as academic problem solving and supervision of academic activities. Teachers' decision-making power on academic affairs is a guarantee to ensure that the academic affairs of the university are effectively controlled to promote academic progress.

Secondly, modern universities should follow the pattern of American research university academic senates to build a complete academic senate system with clear stipulations. For example, generally speaking, there is a charter for the 
academic senates of American research universities, which specifically stipulates the composition of the academic senate, the responsibilities of members, running model, general meeting details and decision-making processes, etc., so as to ensure the activities of the academic senate. Because in the absence of relevant and complete systems, the academic senate cannot guarantee the right of teachers to participate in university decision-making. Teachers will not be able to give full play to their role in the academic governance of the university due to the imperfect organizational system. In order to ensure the enthusiasm of teachers, modern universities should actively improve the relevant organizational system of the academic senate, and grant and respect teachers' power of participating in the management of university internal academic affairs.

Finally, modern universities should balance the relationship between administrative power and academic power within the university. If the university's internal academic decision-making institutions and administrative management institutions are not clear, then the academic senate will not be able to perform academic management functions well. The academic power and administrative power of American research universities are relatively separated but cooperate with each other. This model can not only ensure administrators to respect the academic authority of the academic senate, but also promote the communication and cooperation between the two organizations on major issues which could provide a strong guarantee for the development and governance of the university.

The American research university academic senate has maintained the academic power of American research universities through the implementation of some systems, and effectively promoted the development of American research universities. By utilizing several research methods, this study figures out the functions, running model and characteristics of academic senate of American research universities with reference value which is of great importance to accelerate the development and construction of other modern universities' academic senate system.

\section{ACKNOWLEDGMENT}

This work was supported by the International Cooperation and Exchange Department of Northeastern University foundation project "Research project on STEEM of American Universities (02030022120006)".

\section{REFERENCES}

[1] Y.T. Gan, Z.H.Shan, Exploration on the senate system in American universities, University Education Science, 1, (2010) 97-101. (In Chinese)

[2] Y.T.Gan, The senate in American research-oriented universities in historic coordinates, Higher Education Development and Evaluation, 28(1), (2012) 68-76, 119120. (In Chinese)

[3] W.L. Guo, C.L.Lin, Operation model of American academic senate, Global Education, 41(4) (2012) 67-72. (In Chinese)

[4] X.Y.Ge, Analysis and enlightenment of the characteristics of professors' associations in foreign universities, Modern University Education, 5(2009) 5357. (In Chinese)

[5] Stanford University, Academic Council Committees[EB/OL].[2020-11-10] https://facultysenat e.stanford.edu/academic-council-committees.

[6] The University of Virginia, Faculty Senate Constitution and Bylaws[EB/OL].[2020-11-10] https://f acultysenate/c-blaws.html.

[7] Massachusetts Institute of Technology, Academic Council[EB/OL]. [2020-11-15] http://orgchart.mit.edu/ academic-council.

[8] Boston University, Faculty Handbook [EB/OL]. [2020-11-10] https://www.bu.edu/handbook/.

[9] S. Zhang, Z.M. Liu, The development process, organizational structure and operating characteristics of the Academic council of the University of California, Higher Education Exploration, 11(2015) 53-58. (In Chinese). 